\title{
A HISTORY OF PEBBLES AND SILT - FLUVIAL SEDIMENT TRANSPORT, HYDROPOWER AND TECHNICAL EXPERTISE AT THE AUSTRIAN DANUBE AND ITS TRIBUTARIES
}

\author{
Angelika SCHODER * \\ * Institute of Social Ecology, Alpen-Adria-Universität (AAU) Klagenfurt, Schottenfeldgasse 29, \\ Vienna, Austria, AT-1070, angelika.schoder@aau.at
}

DOI: 10.1515/trser-2015-0083

KEYWORDS: hydropower, sediment regime, environmental history, technical experts, Danube tributaries.

\section{ABSTRACT}

The paper investigates experts' perceptions of hydropower, sediment regime, and their interaction in the 20th century with an environmental historical approach, based on various case studies at both the Danube River and one of its tributaries, and on a review of contemporary literature authored by engineers. Results show that questions of sediment continuity have engaged planners of hydropower plants since the advent of this technology, and decisions were at any time influenced by multiple interests (navigation, electricity demand, nature conservation). In such an intricate fluvial landscape, phenomena like reservoir sedimentation and riverbed incision can be approached as "legacies" of past technical interventions, which limit the options of current and future river management.

ZUSAMMENFASSUNG: Umwelthistorische Überlegungen zu Sedimenttransport, Wasserkraft und Expertenwissen an der österreichischen Donau und ihren Zubringern.

Der Beitrag untersucht Expertenwahrnehmung von Wasserkraft, Feststoffhaushalt und deren Wechselwirkung im Verlauf des 20. Jahrhunderts, basierend auf Fallstudien an der Donau und an einem ihrer Zubringer, sowie publizierten Arbeiten zeitgenössischer Ingenieure. Die Ergebnisse zeigen, dass sich letztere seit Beginn der Wasserkraftnutzung mit Fragen der Sedimentdurchgängigkeit beschäftigten, und dass Entscheidungen von vielfältigen Interessen (Schifffahrt, Strombedarf, Naturschutz) beinflusst wurden. In einer komplexen Flusslandschaft können Phänomene wie Speicherverlandung und Sohleintiefung als langfristige Nebenwirkungen ("legacies") vergangener technischer Eingriffe betrachtet werden, die den Rahmen für aktuelle wie auch zukünftige wasserwirtschaftliche und flussbauliche Möglichkeiten vorgeben.

REZUMAT: O istorie a pietrişului și nămolului - transportul sedimentelor fluviale, hidroenergia și expertiza tehnică a Dunării și a afluenților săi din sectorul austriac.

Lucrarea prezintă percepția specialiștilor în hidroenergie, regimul sedimentelor și interacțiunea lor în secolul 20, cu o abordare istorică a mediului, bazată pe diverse studii de caz, atât pentru fluviul Dunărea cât și pentru unul dintre afluenții săi, precum și o trecere în revistă a literaturii contemporane specializate semnată de ingineri. Rezultatele arată că problemele legate de continuitatea sedimentelor au determinat angajarea de planificatori de centrale hidroelectrice încă de la apariția acestei tehnologii, iar deciziile au fost, în orice moment, influențate de interese multiple (navigație, cererea de energie electrică, dconservarea naturii). Într-un astfel de peisaj fluvial complicat, fenomene precum sedimentarea din rezervor și incizia albiei fluviului pot fi abordate ca „moșteniri” ale intervențiilor tehnice anterioare, care limitează posibilitățile de gestionare curente și viitoare ale râului. 


\section{INTRODUCTION}

Sediment transport plays a key role for sustainable management of the Danube River. In the upper part of its catchment, "hydromorphological" pressures have been identified as important obstacles for reaching the goals of the EU Water Framework Directive (2000/60/EC), and such pressures can be attributed - amongst other causes - to impoundment by hydropower plants (BMLFUW, 2010, 2015). However, a rivers' morphology is not only linked with hydrological aspects, but also with its sediment regime, i.e. processes of erosion, transfer, and deposition of solid material, which is transported either at the riverbed (bedload) or in the liquid phase (suspended load) (Mangelsdorf et al., 1990). From the perspective of fluvial ecology, hydromorphology and sediment regime influence abiotic habitat conditions like flow velocities, temperature, and oxygen content (Jungwirth et al., 2003), are therefore important to observe in river restoration projects with the aim to improve the "ecological state" (Hajdu and Kelemen, 2009; Hohensinner and Jungwirth, 2016). Fluvial landscapes with little anthropogenic alterations are generally characterized by a "dynamic equilibrium" of erosion and deposition, which means that in the long term neither aggradation nor degradation of the riverbed occur (Habersack et al., 2012). However, in the Austrian part of the Danube catchment, interruptions of sediment continuity exist, which most likely affect the whole river basin. One of them, dams and weirs of hydropower plants, are a focus of this paper.

In Austria, hydropower plays an important economic role; it contributes to approximately two thirds of the country's annual electricity generation, and one third comes from large run-of-river plants at the Danube (Wagner et al., 2015). The latter have been built in the second half of the 20th century, later than many of its tributaries where hydropower development started at the end of the 19th century. Dams and weirs of hydropower plants interact with the flow of water and sediments in a river, causing morphological changes like reservoir sedimentation upstream and riverbed incision downstream - or, more generally speaking, leading to a surplus or deficit of material in certain river sections (Brandt, 2000; Schoder, 2013; Habersack et al., 2013). This can have negative consequences for both society (e.g. increased flood risk) and ecosystems (e.g. desiccation of floodplains). Riverbed incision (or riverbed degradation - the two terms will henceforward be used synonymously) has become regarded as a challenge downstream Vienna, in one of the two remaining free-flowing sections of the Austrian Danube (cf. e.g. Klasz et al., 2016). Now the question arises of how to deal with this problem, especially considering that part of the adjacent floodplain is protected as a national park (Nationalpark Donau-Auen) since the prevention of a hydropower plant at this site is a debated issue among river engineers, navigation, and environmentalists (Schoder and Schmid, in press). As the Austrian part of the Danube has a long history of societal use (Schmid, 2013), no single cause of the imbalanced sediment regime can be discerned. It must rather be attributed to multiple interventions in the catchment (e.g. river regulation, torrent control, the construction of storage reservoirs, gravel mining, and land use change) and in the Danube itself. Fluvial landscapes have been transformed in massive river engineering projects in the 19th century, first and foremost by straightening channels and cutting off side arms. How these measures affected the riverbed has been discussed recently by Hohensinner and Jungwirth (2016), who also state that an overall picture of this "third dimension" is still missing, mostly due to a lack of data and sources. About the additional effects of hydropower, little research has been carried out so far, apart from the comparatively well-studied river section downstream of Vienna. 
It is the aim of this paper to explore the interaction of hydropower and sediment regime at the Austrian Danube in the 20th century, from the viewpoint of technical experts, who decided how the river would function after its second big transformation, i.e. the transformation for its energetic use. Were the changes in sediment transport caused by and affecting hydropower really unexpected - or even unintended - by early planners and engineers, or rather consciously accepted with (technical) solutions already at hand? How do past socio-natural interactions affect the implementation of such solutions at present? These questions are addressed using an environmental historical approach. Environmental history studies the interaction of humans and the rest of nature in the past, reconstructing both environmental conditions and the way they were perceived and interpreted by contemporaries (Winiwarter and Knoll, 2007). Especially the last part of this definition is central to this paper, because environmental conditions are approached "through the eyes" of technical experts due to the chosen historical sources (cf. the next section). Studying changing modes of perception can teach important lessons about environmental change, because how humans perceive a river is decisive for how they intervene. Thus, also perception determines material outcomes. The basic assumption of this paper is that for river management, it makes a difference whether experts and decision makers look at water, energy, biota, or at sediments. By choosing such an approach, oriented rather towards social sciences and humanities, this contribution is in line with the general working program of the expert group on "Long-Term Socio-Ecological Research (LTSER) and Environmental History", recently established with the International Association for Danube Research (IAD) (Schmid and Haidvogl, 2015).

\section{MATERIAL AND METHODS}

Historical research starts with identifying sources to answer the research questions. The archival sources used here are compiled in the last column of table 1 . They pertain to selected case studies (Fig. 1) - hydropower projects which are analysed in the course of the author's PhD Thesis on the environmental history of hydropower in Austria - and includes reports, protocols, and studies. These have been written by experts associated with energy companies, administrations, and universities. Table 1 also includes information on selected features of the geomorphological and socio-economic background of the investigated hydropower plants, as it is assumed that both affect their interaction with sediment regime, and perceptions of planners, as well as the public. To complement these site-specific sources, a search of Austrian library databases and review of publications by the Austrian association of engineers and architects (Österreichischer Ingenieur- und Architektenverein, ÖIAV, journals and monographs between 1900 and 1925), have been carried out. These sources were interpreted to reconstruct what Austrian engineers and planners wrote on the topic of hydropower and sediment regime in approximately the first half of the 20th century.

In the next step, these sources were systematically evaluated using the methodological framework of historical discourse analysis (Landwehr, 2008). This approach, which cannot be elaborated here in detail, analyzes what certain actors said or wrote about a specific topic, and the (medial, institutional, political, etc.) context in which this was done. The guiding research questions were, what planners of hydropower plants wrote about the interaction of hydropower and fluvial sediment regime, and how they perceived related challenges (sediment surplus or deficit) - if they did so at all. Particular attention was also paid to which interests of certain stakeholders (e.g. riparian and navigation), the engineers and planners had to observe in this regard. The investigated period was divided into three phases, and the results of this analysis are presented in the following section and finally summarized in a schematic drawing (Fig. 4). 
Table 1: Overview of case studies, selected features of their geomorphological and socio-economic background, and historical sources.

\begin{tabular}{|c|c|c|c|c|c|}
\hline $\begin{array}{l}\text { Name/location } \\
\text { of } \\
\text { hydropower } \\
\text { project }\end{array}$ & $\begin{array}{l}\text { Period of } \\
\text { planning }^{\mathrm{a}} \\
\text { and } \\
\text { construction }^{\mathrm{b}}\end{array}$ & River & $\begin{array}{l}\text { Geology, (original) } \\
\text { river morphology }\end{array}$ & $\begin{array}{l}\text { Main pre- } \\
\text { existing uses } \\
\text { of river and } \\
\text { floodplain }\end{array}$ & Used archives \\
\hline Wienerbruck & $\begin{array}{l}\text { a } 1906-1908 \\
\text { b } 1908-1911\end{array}$ & $\begin{array}{l}\text { Erlauf, } \\
\text { Lassing- } \\
\text { bach }\end{array}$ & $\begin{array}{l}\text { Northern Limestone } \\
\text { Alps; } \\
\text { constrained/pendulous } \\
\text { morpholology }\end{array}$ & $\begin{array}{l}\text { Timber } \\
\text { floating, mills } \\
\text { and small } \\
\text { hydropower, } \\
\text { tourism } \\
\text { (hiking) }\end{array}$ & $\begin{array}{l}\text { EVN-Archiv, } \\
\text { Maria } \\
\text { Enzersdorf }^{\mathrm{d}}\end{array}$ \\
\hline Wallsee & $\begin{array}{l}\text { a } \text { oldest } \\
\text { plans } 1910 \\
\text { b } 1965-1968\end{array}$ & Danube & $\begin{array}{l}\text { Anabranching river in } \\
\text { alluvial plain } \\
\text { (Molasse) }\end{array}$ & $\begin{array}{l}\text { Navigation, } \\
\text { agriculture }\end{array}$ & $\begin{array}{l}\text { OÖ } \\
\text { Landesarchiv, } \\
\text { Linz }^{e}\end{array}$ \\
\hline $\begin{array}{l}\text { Ybbs- } \\
\text { Persenbeug }\end{array}$ & $\begin{array}{l}\text { a oldest } \\
\text { plans } 1922 \\
1942-1944, \\
1954-1959\end{array}$ & Danube & $\begin{array}{l}\text { Constrained } \\
\text { morphology (Danube } \\
\text { cutting through } \\
\text { Bohemian Massif) }\end{array}$ & $\begin{array}{l}\text { Navigation, } \\
\text { agriculture }\end{array}$ & ÖNB, Vienna ${ }^{\mathrm{f}}$ \\
\hline Vienna & $\begin{array}{l}\text { a different } \\
\text { sites } \\
\text { discussed at } \\
\text { least since } \\
1910 \\
\text { b Freudenau } \\
\text { plant built } \\
\text { 1992-1998 }\end{array}$ & Danube & $\begin{array}{l}\text { Anabranching river in } \\
\text { alluvial plain } \\
\text { (Molasse) }\end{array}$ & $\begin{array}{l}\text { Navigation, } \\
\text { urban } \\
\text { infrastructure, } \\
\text { national park } \\
\text { (since 1996) }\end{array}$ & $\begin{array}{l}\text { Misc. university } \\
\text { libraries/archives } \\
\text { and Archiv } \\
\text { DonauConsult } \\
\text { Vienna }\end{array}$ \\
\hline Wachau & $\begin{array}{l}\text { a } 1971-1983 \\
\text { b plant not } \\
\text { built }\end{array}$ & Danube & $\begin{array}{l}\text { Constrained } \\
\text { morphology (Danube } \\
\text { cutting through } \\
\text { Bohemian Massif) }\end{array}$ & $\begin{array}{l}\text { Navigation, } \\
\text { viticulture } \\
\text { and orchards, } \\
\text { tourism }\end{array}$ & $\begin{array}{l}\text { Privatarchiv } \\
\text { Arbeitskreis } \\
\text { Wachau, Spitz }^{\text {a.d. Donau }}{ }^{\mathrm{i}}\end{array}$ \\
\hline
\end{tabular}

${ }^{c}$ Refers to location of the dam or weir, based on: Muhar et al. (2004), Hohensinner and Jungwirth (2016).

${ }^{\mathrm{d}}$ Misc. technical reports (acc. no. 845-4 to 845-8) and legal protocols (acc. no. 845-9-8).

e "Erkenntnis über die wasserrechtliche Verhandlung zur Errichtung des Donaukraftwerkes Wallsee”, 1919 (Bestand Strombauleitung Grein, Schachtel 9, Stammzahl 329).

${ }^{\mathrm{f}}$ Grzywienski, 1949.

${ }^{\mathrm{g}}$ Universität für Bodenkultur, 1991; Bundesministerium für Land- und Forstwirtschaft, 1996.

${ }^{\text {h }}$ Söllner, 1943.

${ }^{\mathrm{i}}$ Grubinger, 1979. 


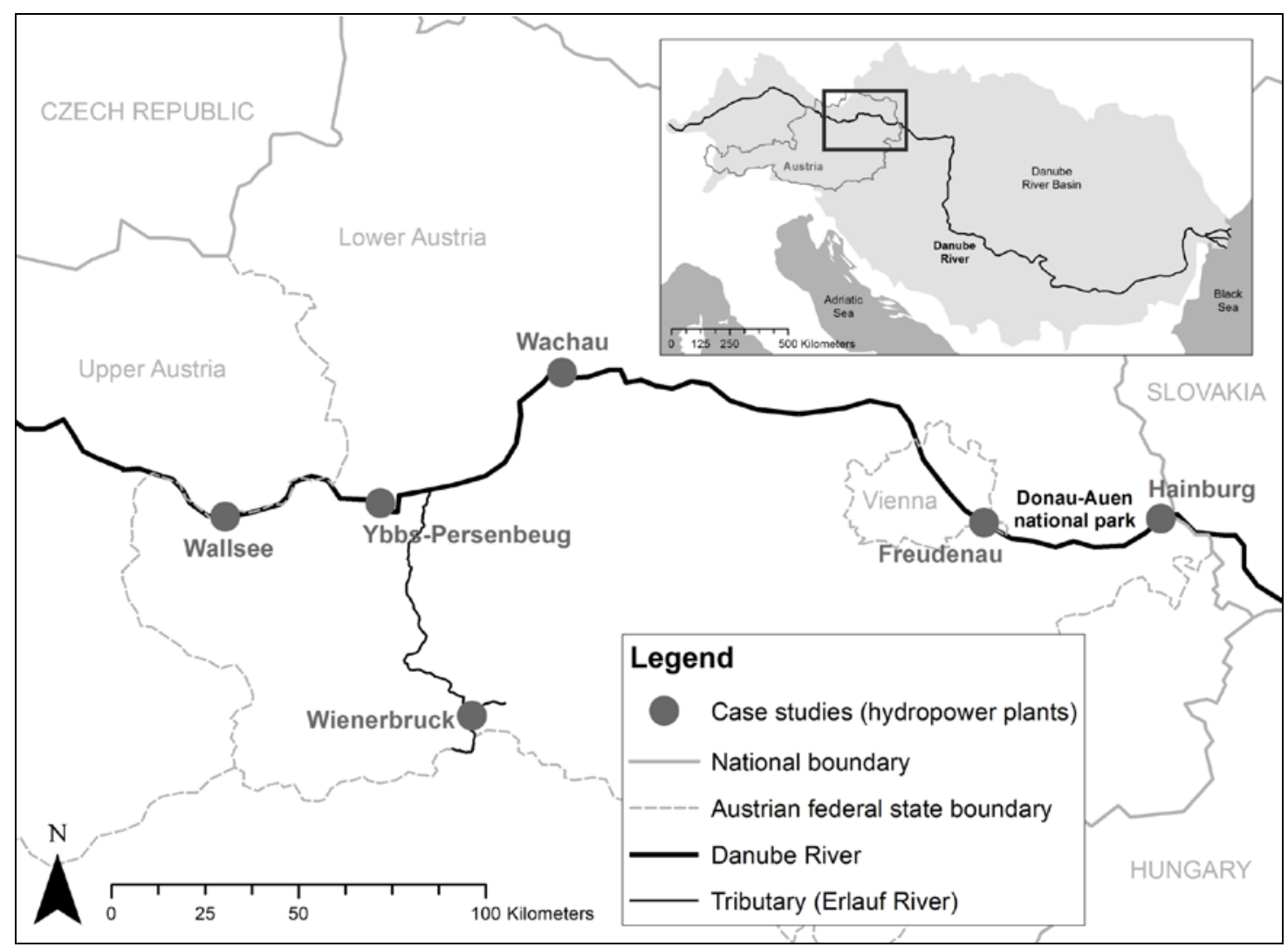

Figure 1: Location of case study sites in the project area in eastern Austria, and within the Danube River basin.

\section{RESULTS AND DISCUSSION}

Three distinct phases can be identified for hydropower development at the Austrian Danube. The first phase ("Vision"), covers the period from approximately 1900 to 1940, when first plants at the Danube were planned, but not yet realized. While plants of different types and sizes were already built at the tributaries, various obstacles existed at Austria's largest river, economic and technical uncertainties being perhaps the most important. Technical experts and investors alike were uncertain whether: enough demand existed for such large amounts of electricity, if storage capacities were lacking, if navigation was strongly opposed to those plans, and if the bedload question was unresolved (Schoder and Schmid, in press). Construction of the first plant at the Austrian Danube (Ybbs-Persenbeug) started during the National Socialist regime. War economy made it necessary to stop the work, which was resumed in the 1950s, only due to unclarified ownership of the project.

A framework plan for the Austrian Danube (Donaurahmenplan) was published in 1955 by Österreichische Donaukraftwerke AG (DoKW), the corporation in charge of developing hydropower along this river since 1947, and four plants were completed by 1970. For this second phase (“Implementation”), approximately from 1940 to 1970, a highly technocratic approach to planning is characteristic. 
In the 1970s, for the first time a plant in the planning stage had to be stopped because of civil protests (cf. case study Wachau), which marks the beginning of the third phase ("Ecology"). Its title hints at two interlinked societal phenomena, which is on the one hand an increased ecological awareness in the general public, and on the other hand the need that planners of hydropower plants consider knowledge about ecological processes in rivers and floodplains in order to reach acceptable solutions. This is also reflected in new international agreements (e.g. Ramsar Convention on wetlands), national legislation (e.g. nature protection laws), and the establishment of protected zones (e.g. national parks).

While such a chronological division can never be clear-cut - one must keep in mind that not all plans of the 1940s were actually implemented, and that six more hydropower plants were completed at the Austrian Danube after 1970 - it provides a useful framework particularly to analyse how broader societal circumstances of hydropower development changed during the 20th century.

Phase 1: Vision (1900-1940)

"We should not regard bedload transport as an illness of the river; it can be slowed down by human interventions, but never be brought completely to a standstill”. (Halter in Grünhut, 1919)

Results of literature review (Tab. 2) show that interactions of hydropower plants with rivers' sediment regime are by no means a recent field of research; the first studies dealing with this topic go back to the advent of hydroelectricity in the late 19th and early 20th century. The literature cited in table 2 includes articles and printed speeches by experts from the fields of hydraulic, agricultural and civil engineering, electricity industry, and navigation, all written to contribute to the contemporary debate on water management and hydropower development in Austria. The authors address their professional peers in the ÖIAV and they also want to reach decision-makers with their recommendations; some want to promote their specific hydropower projects. The Danube as well as its Alpine tributaries are covered, and different aspects of sediment regime which are also nowadays known (except for ecological questions) are addressed: interrupted continuity of bedload and suspended load, upstream challenges (the majority of studies deal with the topic of reservoir sedimentation), but also downstream effects (riverbed degradation is for the first time explicitly addressed by Schoklitsch, 1935). Conclusions or proposed solutions vary according to the focus of the studies. Some articles acknowledge basin-wide processes and challenges of sediment continuity and hydropower (Singer, 1909; Putzinger, 1923) - and come up with interesting suggestions, like using only selected catchments for hydropower and harnessing those completely, starting upstream (Singer, 1909). Others propose solutions for the problem of siltation of Alpine reservoirs or sedimentation in impoundments of run-of-river plants (Halter, 1913; Hauptner, 1914; Putzinger, 1923; Schoklitsch, 1935). It is striking that the majority of currently applied methods (Schoder, 2013) are obviously already known and used. Many studies attempt to quantify sediment transport and bed level changes, although mostly without coming to a precise conclusion. An exception is Schoklitsch (1935), who studied a large number of hydropower plants and included in his comprehensive literature review previous research that dates back to the end of the 19th century. In the contemporary debates (ÖIAV, 1917; Grünhut, 1919, 1922) about hydroelectricity at the Danube and its tributaries (covering also some rivers outside the Danube Basin), many experts acknowledge that sediment transport is an important topic, but they are vague about actual changes that might occur. For the Danube River itself, they mostly address a surplus of bedload and its effects on navigation or reservoir functioning. 
Table 2: Results of literature review, studies mentioning hydropower and sediment regime, 1900-1940.

\begin{tabular}{|c|c|c|c|c|c|c|c|c|c|}
\hline \multirow[b]{2}{*}{ Reference } & \multirow[b]{2}{*}{$\begin{array}{l}\text { River } \\
\text { (type) }\end{array}$} & \multicolumn{7}{|c|}{ Topics covered $^{\mathrm{a}}$} & \multirow[b]{2}{*}{$\begin{array}{l}\text { Conclusions and/or } \\
\text { proposed solutions }\end{array}$} \\
\hline & & 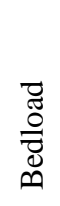 & 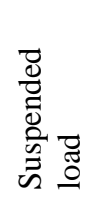 & 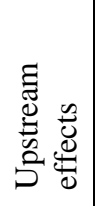 & 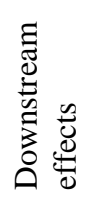 & 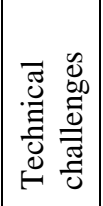 & 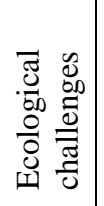 & 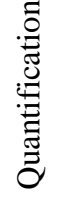 & \\
\hline $\begin{array}{l}\text { Singer, } \\
1909\end{array}$ & $\begin{array}{l}\text { Alpine } \\
\text { streams }\end{array}$ & (X) & $(\mathrm{X})$ & $X$ & $\mathrm{X}$ & $X$ & & & $\begin{array}{l}\text { Use only selected } \\
\text { catchments for hydropower } \\
\text { and develop those } \\
\text { completely, starting } \\
\text { upstream. }\end{array}$ \\
\hline $\begin{array}{l}\text { Halter, } \\
1913\end{array}$ & $\begin{array}{l}\text { Large } \\
\text { rivers } \\
\text { (mainly } \\
\text { Danube) }\end{array}$ & $\mathrm{X}$ & & $\mathrm{X}$ & & $\mathrm{X}$ & & $\mathrm{X}$ & $\begin{array}{l}\text { Flushing and dredging } \\
\text { needed, diminishing } \\
\text { economic returns of } \\
\text { hydropower plants. }\end{array}$ \\
\hline $\begin{array}{l}\text { Hauptner, } \\
1914\end{array}$ & $\begin{array}{l}\text { Alpine } \\
\text { streams }\end{array}$ & $\mathrm{X}$ & $\mathrm{X}$ & $\mathrm{X}$ & & $\mathrm{X}$ & & & $\begin{array}{l}\text { Flushing, dredging, pre- } \\
\text { impoundment basins, } \\
\text { diversion channels and } \\
\text { tunnels, dead storage } \\
\text { capacity, dam elevation, } \\
\text { training works in reservoir. }\end{array}$ \\
\hline $\begin{array}{l}\text { ÖIAV, } \\
1917\end{array}$ & Danube & (X) & & & & $(\mathrm{X})$ & & & $\begin{array}{l}\text { Bedload transport needs to } \\
\text { be observed when a plant is } \\
\text { built (referring to Halter, } \\
\text { 1913). }\end{array}$ \\
\hline $\begin{array}{l}\text { Grünhut, } \\
1919\end{array}$ & $\begin{array}{l}\text { Alpine } \\
\text { streams } \\
\text { and large } \\
\text { rivers }\end{array}$ & $\mathrm{X}$ & & $\mathrm{X}$ & $(\mathrm{X})$ & $\mathrm{X}$ & & & $\begin{array}{l}\text { Large reservoirs should be } \\
\text { built in the Bohemian } \\
\text { Massif rather than the Alps, } \\
\text { because the former is less } \\
\text { prone to erosion and } \\
\text { sedimentation. }\end{array}$ \\
\hline $\begin{array}{l}\text { Grünhut, } \\
1922\end{array}$ & Danube & $\mathrm{X}$ & & & & $\mathrm{X}$ & & $\mathrm{X}$ & $\begin{array}{l}\text { Sedimentation will raise the } \\
\text { bed in reach with residual } \\
\text { flow, interactions with } \\
\text { navigation needs to be } \\
\text { observed. }\end{array}$ \\
\hline $\begin{array}{l}\text { Putzinger, } \\
1923\end{array}$ & $\begin{array}{l}\text { Alpine } \\
\text { streams } \\
\text { and large } \\
\text { rivers }\end{array}$ & $\mathrm{X}$ & $(\mathrm{X})$ & $\mathrm{X}$ & $\mathrm{X}$ & $\mathrm{X}$ & & & $\begin{array}{l}\text { Complete suppression of } \\
\text { sediment transport is not } \\
\text { desirable; measures should } \\
\text { ensure continuity of material } \\
\text { (flushing, diversion, } \\
\text { dredging with deposition). }\end{array}$ \\
\hline $\begin{array}{l}\text { Schoklits } \\
\text { ch, } 1935\end{array}$ & $\begin{array}{l}\text { Alpine } \\
\text { streams } \\
\text { and large } \\
\text { rivers }\end{array}$ & $\mathrm{X}$ & $\mathrm{X}$ & $\mathrm{X}$ & $\mathrm{X}$ & $\mathrm{X}$ & $(\mathrm{X})$ & $\mathrm{X}$ & $\begin{array}{l}\text { Most current measures of } \\
\text { sediment management } \\
\text { mentioned, including the } \\
\text { impact of reservoir flushing } \\
\text { on fish fauna. }\end{array}$ \\
\hline
\end{tabular}

${ }^{a} \mathrm{X}$ signifies that topic is more extensively covered, (X) that it is only briefly or implicitly mentioned. 
This proves that processes and challenges associated with hydropower and fluvial sediment regime were known among technical experts at least since the early 20th century, especially those deriving from a surplus of material. However, what was the role of this knowledge in actual project planning? The engineers designing the Wienerbruck power station, which was the first genuine storage plant in the Austrian monarchy and completed in 1911, had to deal with various challenges, from applying untried technology in a harsh Alpine environment to negotiating with other water users (e.g. timber floating). Sediment continuity is not an issue they addressed in their plans, nor do the preserved legal documents suggest that authorities regarded interrupted sediment transport as problematic, as no respective measures were prescribed. However, later archival material shows that the two reservoirs connected with this plant had to be dredged or flushed several times over the following decades (the larger reservoir at least in the 1940s and 1970s, the smaller one was dredged only a few years ago, Fig. 2). These measures are necessary to maintain the functioning of the reservoir, but are associated with reduced electricity production over a certain period of time and can have negative effects on aquatic organisms (Jungwirth et al., 2003).

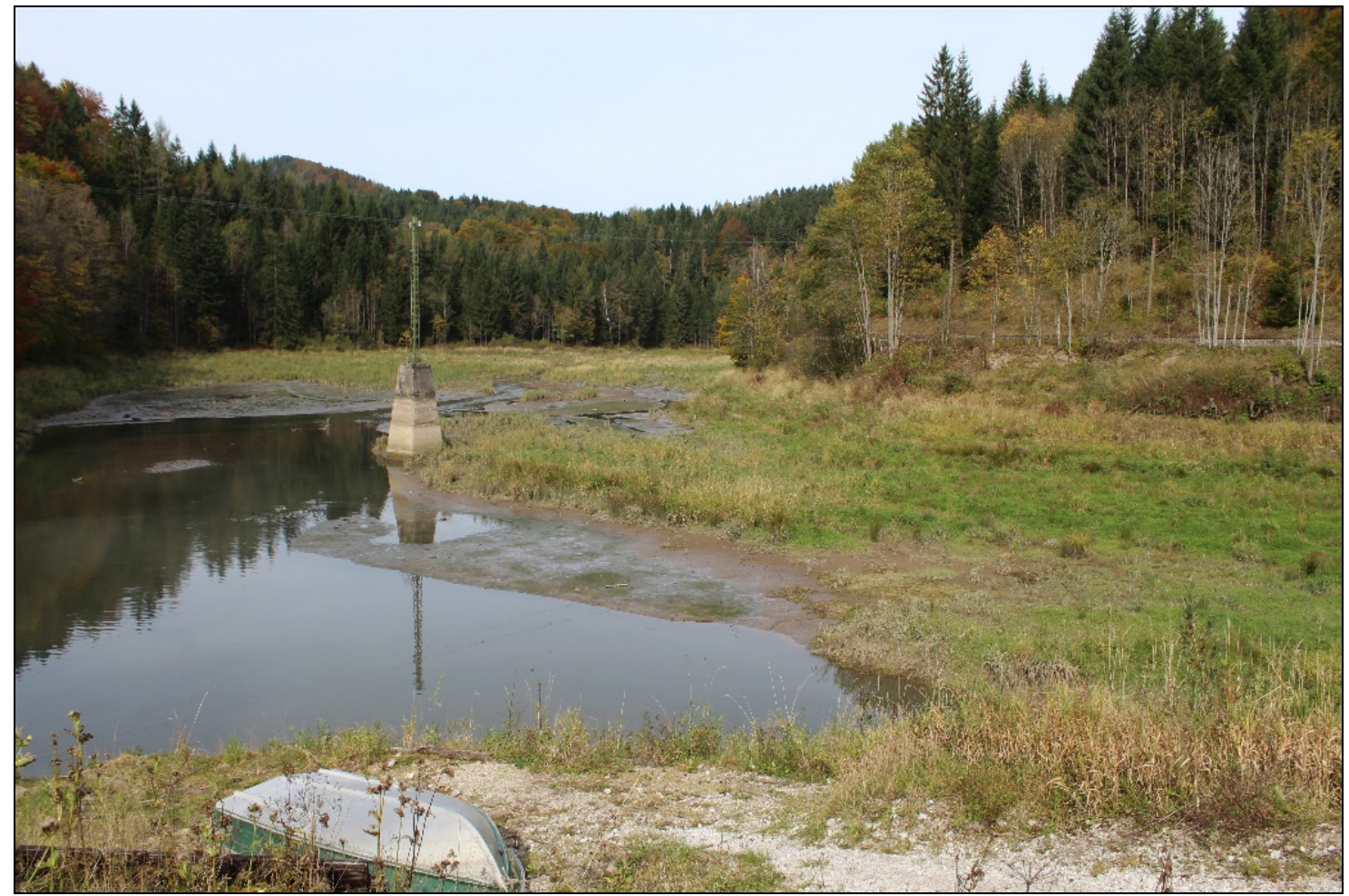

Figure 2: Reservoir siltation at the Erlauf River, a Danube tributary.

The water level is drawn down to allow dredging of deposited gravel, sand, and fine material. 
In contrast to this storage plant located at an Alpine tributary, the Wallsee hydropower project, a run-of-river plant at the Danube for which the first plans were made in 1910, involved a lot of debate about sediment transport. Technical experts expected that deposition of bedload would occur in the Danube upstream of the weir, in the impounded tributaries, and in the residual flow reach. Measures including dredging and flushing were prescribed, as well as additional surveys of the riverbed. The protocol of water law negotiations (1918-1919) demonstrates that local residents and farmers regarded upstream bed level changes and sediment deposition as a threat to their property (due to increased flood risk, impact on water supply and sanitation infrastructure, and change of groundwater levels). Navigation was another important stakeholder that apprehended grievances caused by bedload depositions. As actual implementation in the 1960s differed considerably from these early plans (construction of a river power plant, within the Danube reservoir chain), the actual impacts of this single plant cannot be evaluated here.

Hence, comparing the site-specific plans with more general studies of hydropower and sediment transport in this phase reveals that basin-wide interactions, which in theory were known, were often not observed at the plant scale. If it was addressed at all, the disruption of sediment continuity was regarded merely as a technical problem. The connection of sediment regime and river ecology (e.g. fish fauna) was nowhere considered in the reviewed literature, except for Schokolitsch (1935), who mentions that flushing a reservoir might have negative impacts on the fish population due to increased concentration of suspended sediments. The reason for the identified gap between theoretical knowledge of sediment transport and applied practice of hydropower planning might be a pragmatic one. If the warnings from more cautious experts (e.g. Singer, 1909), had been observed, this would have considerably slowed down hydropower development in Austria - and most engineers at that time agreed that Austria was already late in exploiting this valuable resource, compared to other countries, e.g. Switzerland (cf. Schoder, in press). Moreover, siltation of Alpine reservoirs, which was the most important known impact of disrupted sediment continuity, comes with a considerable time lag, which might explain why it was not considered as urgent problem in the planning stage. The Danube itself remained still free of hydropower plants in this phase, and unclarified issues of bedload transport (especially its interaction with navigation) were an important obstacle. Nevertheless, debates about the first schemes and projects also reveal that the river's sediment regime was already affected by plants at the tributaries and 19th century river regulation - but exactly to what extent remained mostly obscure to technical experts.

Phase 2: Implementation (1940-1970)

"May the construction of large river power plants, which could bring about unwanted or even dangerous effects without mastering the bedload problem, provide us again with occasion for new successful research (...)?”. (Lanser, 1953)

Phase II witnessed a comprehensive framework plan which aimed at complete exploitation of the Austrian Danube's energetic potential, the completion of the first four plants, but also saw (at least) one unsuccessful scheme. 
Plans for a diversion plant at Fischamend, shortly downstream of Vienna and the later constructed plant Freudenau at the south-eastern edge of the city (Fig. 1), to some extent cover the topic of sediment regime. Those plans were submitted in 1943 by the engineer Karl Söllner, who estimated that annually transported quantities of bedload amounted to 350,000 to $450,000 \mathrm{~m}^{3}$, and that thereof 250,000 to $350,000 \mathrm{~m}^{3}$ would have to be dredged, unless they would be flushed during floods. Interestingly, he assumes an "almost stationary state of the riverbed" due to the Danube's regulation, in the river stretch at Vienna and downstream (Söllner, 1943). This statement corresponds to recently published data showing that the effects of regulation were in fact temporally highly variable. Iinitially, a large amount of bedload was released from the regulated stretch at Vienna and deposited in the immediately following river sections. Later, this material was transported further downstream, leading to rather stable bed levels for some decades (since 1930 to 1940) in those sections, followed by conditions of riverbed incision (Hohensinner and Jungwirth, 2016; Klasz et al., 2016; based on Schmautz et al., 2002). Apparently Söllner, at his time, saw only a part of this bigger picture; he missed the necessary long-term perspective and in this sense came up with a false estimation of the general challenge.

Deviations can be observed in the figures for bedload transport (and also in the methods to determine them), when only a few years later quantities at Ybbs-Persenbeug (upstream, Fig. 1) were estimated at an annual average of $400,000 \mathrm{~m}^{3}$ and a maximum of $600,000 \mathrm{~m}^{3}$ (Grzywienski, 1949). The author studying this site, where construction of the first Danube plant had started in 1942, concluded that the majority of this material would need to be dredged, although part of it might be used for construction purposes. He recommended bedload traps at the beginning of the impoundment due to the irregular input of material. It must be noted that both studies did not yet regard the Danube as a chain of plants, although Grzywienski (1949) mentioned that downstream erosion would be reduced by another plant at Melk.

A few years later, the Donaurahmenplan (DoKW, 1955) hardly mentioned sediment transport in its accompanying descriptive text. This document merely states "avoiding aggradation of the riverbed" as a general planning principle (DoKW, 1955); apart from that, it explains how an uninterrupted chain of hydropower plants would exploit the Danube's hydropower potential most efficiently, and how navigation would benefit from the increased water depths. An incised riverbed was regarded as positive to increase useable head and should for some plants be achieved "artificially" with dredging (DoKW, 1995). After all, hydropower at that time was regarded as a means to reconstruct the war-torn country and to overcome energy shortages, and plants at the Danube enjoyed priority due to their large contribution to this end (Vas, 1956). However, in the eyes of other experts, questions about quantifying processes at the riverbed, let alone ensuring continuity of sediments, were far from being resolved. Two years earlier, civil engineer Otto Lanser, who had been involved in many hydropower projects before, pointed out the need to develop quantification methods further, especially in the light of building hydropower plants at the Danube, but he also expressed a lot of optimism about technical and scientific progress in this regard (Lanser, 1953). Despite the lack of accurate insights into processes at the riverbed, the first two plants of the Donaurahmenplan (Jochenstein at the Austrian-German border, and Ybbs-Persenbeug; Fig. 3), were finished by 1960, and two more plants started operation by 1970 . 


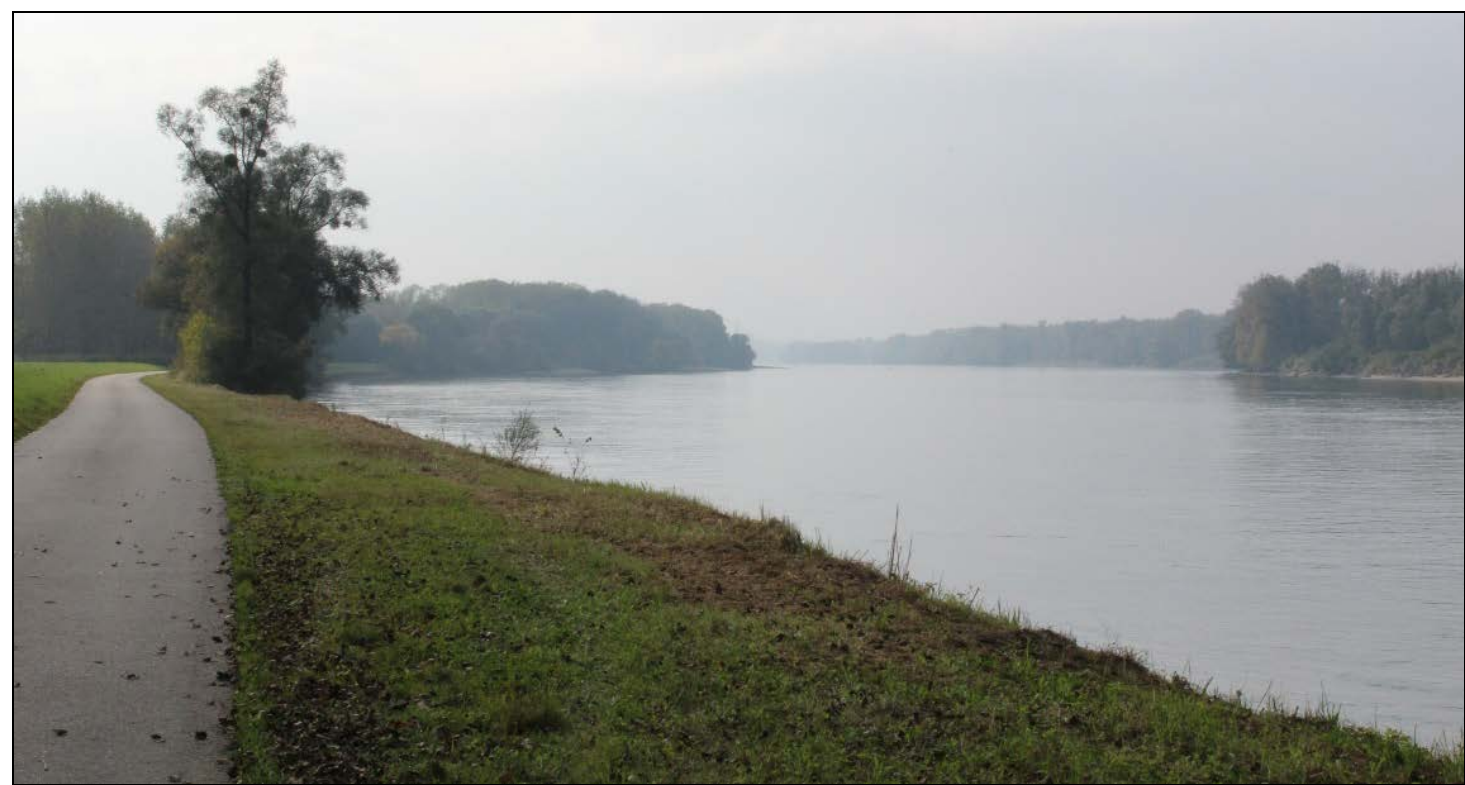

Figure 3: Impoundment of Ybbs-Persenbeug, one of the ten run-of-river plants at the Austrian Danube (picture taken by the author in October 2014). Prior to "rectification" in the 19th century, the river had at this site anabranching channel morphology.

Phase 3: Ecology (1970-2000)

"Donaukraft (hydropower operator) has to maintain only the existing riverbed which is defined as the reference bed before impoundment. Beyond this, improvements of navigability are not in the responsibility of Donaukraft". (Bundesministerium für Land- und Forstwirtschaft, 1996)

With six more plants built after 1970, two free-flowing sections remain at the Austrian Danube. They warrant a closer look, because processes at the riverbed were central in the argumentation for and against hydropower plants at these sites, and they challenge experts up to the present. In these sections, flow velocities and sheer stress are higher than in the impoundments, and due to the lack of material input from either upstream or the banks, the river can degrade its bed (Habersack et al., 2012; Klasz et al., 2016).

Riverbed incision was initially used by the electricity industry as an argument to build a power plant in the Wachau section of the Danube, which should ensure that the bed was stabilized and one of the remaining bottlenecks for navigation was removed. Although foreseen in the Donaurahmenplan, this plant was controversial from the beginning, not least because of the importance of tourism and viticulture in the region. Locals feared that the scenery would be impaired by dams, and that vineyards and orchards might be affected by microclimatic changes; they were supported in their protests against the plant by many visitors of the region, and also by some technical experts (Hirtzberger, 1995). Herbert Grubinger (geologist, engineer, and professor at ETH Zürich) came to the preliminary conclusion that riverbed incision would not be a major issue in this river section due to its geomorphology (Tab. 1). Therefore, navigability could be ensured also with conventional river engineering measures (Grubinger, 1979). He recommended that further studies about the riverbed should be made, but in 1983 representatives of DoKW and the Austrian government officially announced that no plant would be built at that site (Hirtzberger, 1995). The region was 
declared UNESCO cultural heritage in 2000, the Wachau is still one of the "bottlenecks" for navigation along the Danube (via donau, 2005), but it seems that riverbed incision indeed is not a major problem, in contrast to the Danube's second free-flowing section east of Vienna.

At that location, another hydropower plant (Hainburg) was stopped due to civil protests in the early 1980s, and a national park was established in 1996 to protect one of the last remaining floodplain forests at the upper Danube (Nachtnebel, 1995; Schmid and Veichtlbauer, 2006; Schoder and Schmid, in press). However, DoKW set out to build another plant upstream, where the impoundment would not interfere with any protected or ecologically sensitive areas (Freudenau plant, completed in 1998). In the meantime, first studies had been carried out detecting and quantifying riverbed incision at the Danube east of Vienna (e.g. Kresser, 1984). Ecological issues related to Danube hydropower plants were investigated in different research projects (e.g. Hary and Nachtnebel, 1989; ARG, 1989; Expertengruppe Untere Donau, 1996). Amongst other insights, they established that changes of the riverbed, water tables both in the Danube and the adjacent groundwater bodies, and floodplain ecology were closely linked. This meant that sediment continuity was important to consider for the planners of the Freudenau plant, in order to not further aggravate the already existing problem of riverbed degradation. Artificial bedload addition was prescribed as a downstream measure, and the average amount of annual material input was estimated at $160,000 \mathrm{~m}^{3}$ in the respective legal document (Bundesministerium für Land- und Forstwirtschaft, 1996). This figure is considerably lower than the amount of sediment transport experts had calculated before the first Danube plants were built, which might be explained with the mostly completed hydropower chain and the different plant sizes and types - after all, the prescribed measure was only to offset the effect of this single plant. However, the cited document also states that the actual amount was to be determined based on detailed riverbed surveys and the calculation of mass balances. Artificial gravel addition at the Danube east of Vienna is still ongoing and riverbed incision remains a challenge not yet entirely resolved, although in the meantime revised projects have been proposed based on ecologically oriented measures of hydraulic engineering (cf. e.g. Habersack et al., 2012).

To sum up the developments in this last phase, changes of the riverbed and associated problems, which had been to some extent anticipated by experts in earlier phases, became evident in certain river sections. At the same time, ecological properties of rivers and floodplains emerged as an additional (also public and thus political) interest to be observed by planners, and the designation of protected areas excluded certain options (such as "hard" engineering measures or an additional hydropower plant at the Danube east of Vienna).

Synthesis. The fluvial landscape of the Austrian Danube results from the overlaid effects of different phases of river management. Along with the material transformation, also knowledge and expertise of how to initiate and shape this transformation evolved (Fig. 4). Already in Phases I and II, studies of sediment transport and insights into bed level changes at the Austrian Danube and some tributaries (e.g. HZB, 1937; HZB, 1948, cited in Klasz et al., 2016), and experts and planners of hydropower also drew from knowledge of channel morphology dating back to river regulation (e.g. Schoklitsch, 1935; Söllner, 1943). Hydropower development provided a stimulus for more research. In Phase III, methods of quantification were improved in the course of more detailed studies of specific river sections, where issues of sediment regime were perceived as problematic. Monitoring and modelling sediment transport and river morphological changes related to hydropower have of course further evolved in the 21st century (Habersack et al., 2013). However, if and to what extent this knowledge is considered in actual river management and decision making depends on constellations of 
interests in the specific social, political and cultural context of each period. These interests in the fluvial landscape have considerably diversified since Phase III, when in addition to long established stakeholders (navigation, electricity demand, agriculture, infrastructure and settlements in the floodplains) issues like nature protection, cultural heritage, as well as tourism and recreation have to be observed. Some other interests, however, had disappeared from the landscape at a much earlier stage: timber floating, mills, and commercial fishery can be seen as "losers" in the transformation of the Austrian Danube (Haidvogl, 2010).

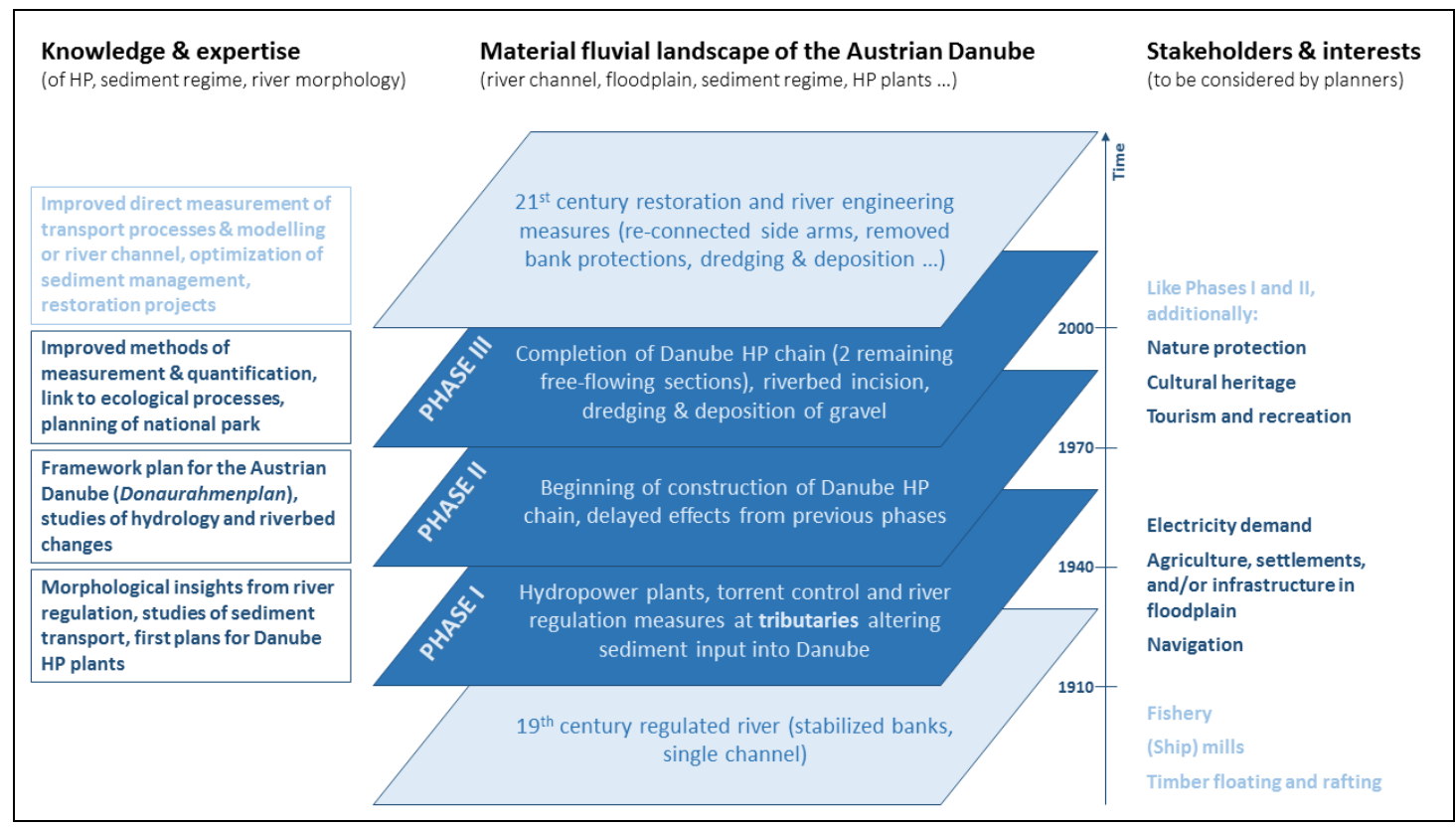

Figure 4: Three dimensions of the Danube's transformation - knowledge and expertise, stakeholders and interests, and different states of the material fluvial landscape.

Figure 2 provides a synthesis of the findings from all phases, each layer representing a historical state of the river; the long-term (side) effects of this state are passed on to later phases and generations as "legacies". The regulated river of the 19th century must be regarded as a merely arbitrary starting point, as the Danube's sediment regime has already been altered in pre-industrial times (Giosan et al., 2012). In any case, such a physically and institutionally complex landscape means that the attribution of individual responsibilities to compensate environmental problems has become increasingly difficult. If DoKW (respectively its legal successor) has to offset only the effects of single plants, who is then responsible to implement measures to tackle the problem of riverbed incision that had already existed or had been initiated before that plant was built? How can demands of navigation, which had been the dominant interest to transform the Danube for centuries, be reconciled with recently emerged needs of nature conservation and a national park? What is an adequate "reference state" of the riverbed that should be the baseline for restoration projects? These are only some of the questions posed by a fluvial landscape which have been so thoroughly transformed like the Austrian Danube. Socio-cultural drivers, like different perceptions of the river and its ideal state, played and still play an important role in shaping this landscape, and environmental history can help to unravel them. 


\section{CONCLUSIONS}

This paper focused on the interaction between hydropower and the Danube's sediment regime, and analysed how it changed in the course of the 20th century. Approaching this link through the writings of engineers and planners of hydropower plants, three dimensions of the Danube's transformation were distinguished. At the level of knowledge and expertise, it became clear that management options (e.g. flushing and dredging) did not change significantly over that time period, but were optimized due to improved methods of quantification and monitoring. In the material fluvial landscape, the effects of different interventions (e.g. river regulation, plants at tributaries, Danube hydropower chain) can hardly be disentangled. As "legacies", they are passed on and limit the options for present and future river management; but on the other hand, they enable certain practices, such as electricity generation and navigation. Looking at the two remaining free-flowing sections of the Austrian Danube has revealed that also site-specific geomorphology and properties of the riverbed matter for actual outcomes (e.g. riverbed incision). Changing modes of perception were central to this study, and it can be concluded that those were closely related to specific constellations of interests in any of the observed phases. For example, interests of electricity generation and navigation caused planners to envisage the Danube as an uninterrupted chain of impoundments after World War II. Some case studies have illustrated how a lack of long-term observation can mean that experts neglect or misjudge processes at the riverbed and their temporal variability. Also nowadays, such a long-term perspective is needed to understand and manage sediment dynamics in the catchment of a large river like the Danube. 


\section{ACKNOWLEDGEMENTS}

The author is recipient of a DOC Fellowship of the Austrian Academy of Sciences at the Institute of Social Ecology, and this research is part of her ongoing dissertation project entitled "Flow regimes - the nature of Austrian hydropower, technical expertise, and environmental discourses in the 20th century". Travel costs for participating in the IAD Conference in Sibiu, Romania have been partially financed by Österreichische Forschungsgemeinschaft (ÖFG, grant 06/14960). The author gratefully acknowledges financial support from AAU Research Council and advice from supervisor Assoc. Prof. Mag. Dr. Martin Schmid, and wants to thank all people and institutions providing access to archival sources. 


\section{REFERENCES}

1. ARG (ed.), 1989 - Interdisziplinäre Studie Donau, Arbeitsgemeinschaft Regional- und Gemeindeplanung im Auftrag des Österreichischen Wasserwirtschaftverbandes, Vienna, 362. (in German)

2. BMLFUW, 2010 - Nationaler Gewässerbewirtschaftungsplan 2009, BMLFUW-UW.4.1.2/0011I/4/2010, Vienna, 225. (in German)

3. BMLFUW, 2015 - Nationaler Gewässerbewirtschaftungsplan 2015, Entwurf, Vienna, 332, (available online at http://wisa.bmlfuw.gv.at/fachinformation/ngp/ngp-2015.html). (in German)

4. Brandt S. A., 2000 - Classification of geomorphological effects downstream of dams, CATENA, 40, 4, 375-401, DOI: 10.1016/S0341-8162(00)00093-X.

5. Bundesministerium für Land- und Forstwirtschaft, 1996 - KW Freudenau, Detailprojekt Unterwasserbereich, wr. Bescheid, Vienna, 36. (in German)

6. DoKW, 1955 - Rahmenplan der österreichischen Donau, 1, Jochenstein-Ybbs, Erläuterung Vienna, 24. (in German)

7. Expertengruppe Untere Donau, 1996 - Donau Wien-Staatsgrenze, Expertenbericht, Österreichische Ingenieur- und Architekten-Zeitschrift, 141, 6, 238-262. (in German)

8. Giosan L., Coolen M. J. L., Kaplan J. O., Constantinescu S., Filip F., Filipova-Marinova M., Kettner A. J. and Thom N., 2012 - Early Anthropogenic Transformation of the Danube-Black Sea System, Nature Scientific Reports, 2, 582, DOI: 10.1038/srep00582.

9. Grubinger H., 1979 - Erwägungen zu den Gutachten der Professoren Dr. Rescher O. und Dr. Wendelberger G. über den Ausbau der Wachau zu einer Wasserstrasse, Zürich/Spitz a.d. Donau, 8. (in German)

10. Grünhut K. (ed.), 1919 - Elektrizitätswirtschaft und Wasserkraftnutzung, Wechselrede gehalten in den Fachgruppen der Bau- und Eisenbahn-Ingenieure und für Elektrotechnik des Oesterreich Ingenieur- und Architekten-Vereines, Urban and Schwarzenberg, Vienna/Berlin, 102. (in German)

11. Grünhut K., 1922 - Über das Maß der Wasserentnahme für ein Donaukraftwerk bei Wien, Zeitschrift des Österreichischen Ingenieur und Architekten-Vereines, 74, 17/18, 75-78. (in German)

12. Grzywienski A., 1949 - Das Donauwerk Ybbs-Persenbeug, Die Entwicklung des Projektes, Springer, Vienna, 58. (in German)

13. Habersack H., Liedermann M., Tritthart M., Hauer C., Klösch M., Klasz G. and Hengl M., 2012 - Maßnahmen für einen modernen Flussbau betreffend Sohlstabilisierung und Flussrückbau - Granulometrische Sohlverbesserung, Buhnenoptimierung, Uferrückbau und Gewässervernetzung, Österreichische Wasser- und Abfallwirtschaft, 64, 11-12, 571-581, DOI: 10.1007/s00506-012-0037-3. (in German)

14. Habersack H., Wagner B., Schoder A. and Hauer C., 2013 - Die Bedeutung von Feststoffhaushalt und Sedimentdurchgängigkeit für eine nachhaltige Nutzung der Wasserkraft, Österreichische Wasser- und Abfallwirtschaft, 65, 9-10, 354-361, DOI: 10.1007/s00506-0130108-0. (in German)

15. Haidvogl G., 2010 - Verschwundene Fische und trockene Auen, Wie Regulierung und Kraftwerksbau das Ökosystem Donau im Machland verändert haben, in Umwelt Donau, Winiwarter V. and Schmid M. (eds), NÖ Landesarchiv, St. Pölten, 119-135. (in German)

16. Hajdu Z. and Kelemen A., 2009 - An ecological reconstruction model of a small tributary, the Dorman Creek, Acta Oecologica Carpatica, II, 199-204.

17. Halter R., 1913 - Großwasserkraftanlagen und Geschiebeführung, Zeitschrift des Österreichischen Ingenieur- und Architekten-Vereines, 65, 19, 289-294. (in German)

18. Hary N. and Nachtnebel H.-P., 1989 - Ökosystemstudie Donaustau Altenwörth, Veränderungen durch das Donaukraftwerk Altenwörth, Universitätsverlag Wagner, Innsbruck, 445, Veröffentlichungen des österreichischen MaB-Programms, 14. (in German)

19. Hauptner R., 1914 - Die Vorkehrungen gegen das Verlanden der Talsperren und Staubecken, Zeitschrift des Österreichischen Ingenieur- und Architekten-Vereines, 66, 4, 66-68. (in German) 
20. Hirtzberger H., 1995 - Zur Geschichte des Arbeitskreises zum Schutz der Wachau, in Die Wachau: Perspektiven einer europäischen Flußlandschaft, Arbeitskreis zum Schutz der Wachau (ed.), Malek, Krems, 129-139. (in German)

21. Hohensinner S. and Jungwirth M., 2016 - Die unbekannte dritte Dimension: Geländehöhen, Gewässertiefen und Dynamik österreichischer Donaulandschaften vor der Regulierung, Österreichische Wasser- und Abfallwirtschaft, 68, 7-8, 324-341, DOI: 10.1007/s00506-0160323-6. (in German)

22. HZB (Hydrographisches Zentralbüro), 1937 - Schwebstoff- und Geschiebeaufnahmen einiger österreichischer Flüsse, Vienna, 16. (in German)

23. HZB, 1948 - Die Abflussverhältnisse der Donau in Österreich 1893-1942, Bearbeitet von Dr. Kresser, Vienna, 112. (in German)

24. Jungwirth M., Haidvogl G., Moog O., Muhar S. and Schmutz S., 2003 - Angewandte Fischökologie an Fließgewässern, Facultas UTB, Vienna, 547. (in German)

25. Klasz G., Gabriel H., Habersack H., Schmalfuß R., Baumgartner C. and Gutknecht D., 2016 Ausmaß und Dynamik der Sohlerosion der Donau östlich von Wien - flussmorphologische und wasserwirtschaftliche Aspekte, Österreichische Wasser- und Abfallwirtschaft, 68, 5-6, 199-207, DOI: 10.1007/s00506-016-0309-4. (in German)

26. Kresser W., 1984 - Donaukraftwerk Hainburg, Eintiefungstendenzen der Donau im Bereich von Greifenstein bis zur Staatsgrenze, Gutachten, Vienna. (in German)

27. Landwehr A., 2008 - Historische Diskursanalyse, Campus, Frankfurt/Main, 187. (in German)

28. Lanser O., 1953 - Die bisherige Entwicklung der Geschiebetheorien und Geschiebebeobachtungen, Blätter für Technikgeschichte, 15, 58-78.

29. Mangelsdorf J., Scheurmann K. and Weiß F.-H., 1990 - River Morphology: A Guide for Geoscientists and Engineers, Springer, Berlin/Heidelberg, Physical Environment, 7, 243.

30. Muhar S., Poppe M., Egger G., Schmutz S. and Melcher A., 2004 - Flusslandschaften Österreichs: Ausweisung von Flusslandschaftstypen anhand des Naturraums, der Fischfauna und der Auenvegetation, Bundesministerium für Bildung, Wissenschaft und Kultur, Vienna, 181. (in German)

31. Nachtnebel H.-P., 1995 - Environmentally and socially sound utilization of floodplains: Some Austrian experiences, in Defence from Floods and Floodplain Management, Gardiner J., Starosolszky Ö. and Yevjevich V. (eds), Kluwer Academic Publishers, Dordrecht/Boston/London, 539-554.

32. Putzinger J., 1923 - Der Geschieberückhalt der Stauseen und seine Einwirkung auf ein Flußgebiet, Zeitschrift des Österreichischen Ingenieur- und Architekten-Vereines, 75, 19/20, 118-120. (in German)

33. Schmautz M., Aufleger M. and Strobl T., 2002 - Anthropogene Einflussnahme auf die Flussmorphologie der Donau in Österreich, Österreichische Ingenieur- und ArchitektenZeitschrift, 147, 5-6, 171-178. (in German)

34. Schmid M., 2013 - Towards an Environmental History of the Danube: Understanding a great European river through its transformation as a socio-natural site, c. 1500-2000, Habilitation thesis, Alpen-Adria-Universität Klagenfurt/Graz/Wien, 476.

35. Schmid M. and Haidvogl G., 2015 - New IAD Expert Group: Long-Term Socio-Ecological Research (LTSER) and Environmental History, Danube News, 31, 2-3.

36. Schmid M. and Veichtlbauer O., 2006 - Vom Naturschutz zur Ökologiebewegung, Umweltgeschichte Österreichs in der Zweiten Republik, Studien-Verlag, Innsbruck, 98.

Schoder A., 2013 - Hydropower developments in Austria: Interaction with sediment regime and river morphology, Master thesis, Universität für Bodenkultur Wien and Lincoln University Christchurch (NZ), 161. 
37. Schoder A., in press - Der Bau des Speicherkraftwerks Wienerbruck: die Transformation einer Landschaft aus der Sicht der Ingenieure, in Mémoire industrielle et phénomènes de patrimonialisation dans les Alpes (19e-20e siècles), Lorenzetti L. and Valsangiacomo N. (eds), Academy Press, Mendrisio. (in German)

38. Schoder A. and Schmid M., in press - Where Technology and Environmentalism Meet: The Remaking of the Austrian Danube for Hydropower, in Environmentalism in Central and South Eastern Europe, Historical Perspectives, Petrić H. and Žebec Šilj I. (eds), Rowman and Littlefield, Lanham.

39. Schoklitsch A., 1935 - Stauraumverlandung und Kolkabwehr, Springer, Vienna, 178. (in German)

40. Singer M., 1909 - Über Wasserwirtschaft im Gebirge, 2, Teil, Zeitschrift des Österreichischen Ingenieur- und Architekten-Vereines, 61, 28, 449-454. (in German)

41. Söllner K., 1943 - Donaukraftwerk Wien-Fischamend, Bericht des Entwurfsverfassers, Vienna, 19. (in German)

42. Wagner B., Hauer C., Schoder A. and Habersack H., 2015 - A review of hydropower in Austria: Past, present and future development, Renewable and Sustainable Energy Reviews, 50, 304-314, DOI: 10.1016/j.rser.2015.04.169.

43. ÖIAV, 1917 - Wien und die Donau, Denkschrift des oesterreichischen Ingenieur- und Architekten-Vereines, Vienna, 63. (in German)

44. Universität für Bodenkultur, 1991 - Prüfung der Umweltverträglichkeit des KW Freudenau nach §§ 104 und 105 WRG, Gutachtliche Schlussfolgerung, Vienna, 61. (in German)

45. Vas O., 1956 - Wasserkraft- und Elektrizitätswirtschaft in der Zweiten Republik, Springer, Vienna, 48, Schriftenreihe des Österreichischen Wasserwirtschaftsverbandes, 30. (in German)

46. Winiwarter V. and Knoll M., 2007 - Umweltgeschichte, Eine Einführung, Böhlau, Köln, 368. (in German)

47. via donau, 2005 - Handbuch Donausschifffahrt, Vienna. (in German) 